\title{
Local Wisdom on Nyadran Tradition in Sragen Regency
}

\author{
K Saddhono $^{1}$, B Setiawan ${ }^{2}$, Yuliningsih ${ }^{3}$, F S Rahmaniar ${ }^{4}$ \\ $\left\{{ }^{1}\right.$ kundharu.uns@gmail.com, ${ }^{2}$ buset.74@yahoo.com, ${ }^{3}$ yuliningsih360@ gmail.com, \\ 4shalzarahmaniar1994@gmail.com \} \\ 1,2,3,4 Universitas Sebelas Maret Surakarta, Indonesia
}

\begin{abstract}
This study aims to describe and to explain local wisdom values in the Nyadran traditional ceremony in Ngepringan Village, Sragem Regency. It was descrptive qualitative with a case study approach. The case study were conducted to give the information about the procession of the nyadran cereony, including procedures, ubarampe used and symbolic meaning. Source of data were informants, events, and documents. Data collection technique deployed interview, field observation and content analysis. The result indicates some facts about the procession of nyadran traditional ceremony, including the procession of cleaning tombs and punden, nyekar (spreading the flower on the tombs), cooking sesaji, bancakan, andum sodakhohan, nyadran to Mbah Gedhon punden, and punggahan. Ubarampe used are apem, kolak, ketan, ingkung, bucu, nasi golong, krupuk abang, egg, kemenyan, nasi uduk, jadah, pisang raja, peyek teri, red rose, and white rose. Local wisdom values in the nyadran traditional ceremony are mutual cooperation, tolerance, harmony, affection, and religious. Some values and philoshopies in the nyadran ceremony are considered revelant for being utilized as learning materials of Javanese subject of SMK (Vocational High School).
\end{abstract}

Keywords: Nyadran Ceremony, Local Wisdom, Symbolic Meaning, Learning Material of Javanese Subject for SMK

\section{INTRODUCTION}

Indonesia is an archipelago county with various cultural wealth. Indonesian people's life become multicultural. Multicultural awareness necessarily has to be implanted in each individual to avoid fatalistic or chauvinism attitude [1]. Consequently, a strategical effort to rebuild values of local wisdom is required by, one of them, basic education. Basic education is a form of multicultural education as a program of implanting the effective enculture of local wisdom values to students in the early age [2]. This is supported by Fitriyani, et al. [3] that one of the efforts to preserve cultural values is through the utilization of local culture in the educational process.

The role of basic education must be appropriate to its academic function and acquire the potentials of local wisdom values as a value-added that can be utilized to maintain social and natural harmonies [4]. This study considers that local wisdoms containing in nyadran tradition has values, manifested in social and traditional rules, such as taking care of nature, being obedient and respecting elders, etc. Hence, these local wisdoms are possibly utilized as a means 
to build children characters. This is similar to as Chotimah [5] who suggested that local wisdoms can be used as a builder of the nation's character.

In the reality, local wisdoms in nyadran tradition have not been relevantly manifested into all subjects. However, the process of internalizing local wisdom values among students has been occurring. Moreover, elementary schools are limited in the conceptual scope, not realized into a concrete life [6]. Through learning materials adjusted to growth level, students are stimulated to be nationalist by integrating local wisdom values in teaching and learning process [7]. As a result, respecting and loving their culture will be built. Local wisdom value-based teaching encourages students to constantly be close and able to solve real problems in their daily life. Besides, their cultural knowledge will become the global and local knowledge as an initial treatment for building character.

Contextualizing knowledge on local wisdoms to reinforce student character becomes urgent to do. This is because of that globalization has involved human need excessively. Moreover, in 2016, Indonesia faces AEC, which is quite competitive and open. This reality has to be response seriously by considering strategical steps unless local wisdom diversity gets distorted, ignored, or even distinct. Therefore, the integration of local wisdom values in strengthening children identity and character become a strategic step that probably anticipates intolerable actions in the social life.

\section{RESEARCH METHODS}

This study deployed descriptive qualitative with mainly focusing on describing and explaining local wisdom values in nyadran tradition to build elementary student characters. Culture-based descriptive qualitative method was a descriptive method and logic definition method relating to values in the culture manifested in the real life. Source of qualitative data was the nyadran traditional ceremony. Data collection technique used observation and in-depth interview to customary stakeholders, elementary teachers, and elementary students. In obtaining the data, informants are selected with reference to research purposes [8]. To assure the data validity, it was needed to test data validity by using data triangulation. The data triangulation was utilized to check the data validity by utilizing other things [9]. Data analysis techniques employed the interactive chain analysis in terms of data reduction, data display and drawing conclusion.

\section{RESULTS AND DISCUSSION}

\subsection{Nyadran Tradition in Sragen Regency}

Nyadran tradition is an ancient heritage developing in Central Java, Indonesia. This tradition is a symbol of human relationship with ancestors, human, and the Almighty God. Ngepringan society have point of view and attitude about life orienting to good values, such as polite, religious, and spiritual [10]. Nyadran in the Javanese society closely relates to sacred values as a realization of the Javanese fidelity toward Allah SWT. The interrelationship between cultural ritual and religion definitely refers to social thing. It indicates that in each culture, religion is the most precious element of the whole social life [11].

Each nyadran process has local wisdom values that can be manifested through basic education, which help students in developing their potentials, skills, and personal character better [12]. This is in line with the Law of the Republic of Indonesia Number 20 Year 2003 on national education system that the goals of national education are to develop abilities and to 
build characters and prestigious national civilization in order to create the intelligent national life. In a consequence, character educations should be early given to students. If students recognize tradition containing moral and character education since the early age, they will have good character as they are grown up [13]. One way to build children character is by introducing traditions containing local wisdom values.

Local wisdom values in the nyadran procession include deliberation, mutual cooperation, environment-caring, communicative, peace-loving, religious, mutual sharing, generous, and harmonious values. The deliberation value is actualized as nyadran committee are being organized. The mutual cooperation and environment-caring values are actualized at the procession of cleaning tombs, punden (a building considered holy by past local society and used as a place for revering ancestors), and village environment. The communicative value is built at the bancakan procession. The religious value is actualized in terms of worshiping Allah SWT through praying. The generous value is represented in the procession of andhum sodaqoh and punggahan. The harmonious value is reflected as the nyadran takes place. Those values of character builders are summarized in the following table.

Table 1.1: local wisdom values in the nyadran procession

\begin{tabular}{lll}
\hline No. & Nyadran Procession & Local Wisdom Value \\
\hline 1. & Organizing nyadran committee & Deliberation \\
2. & Cleaning tombs and punden & Mutual cooperation and environment-caring \\
3. & Cooking foods and sesaji (ritual offerings) & Communicative \\
4. & Bancakan & Religious \\
5. & Andhum sodaqohan & Mutual Sharing \\
6. & Nyadran in Mbah Gedhong punden & Harmonious, religious \\
7. & Punggahan & Generous, religious \\
\hline
\end{tabular}

These values containing in the procession of nyadran ceremony is able to build student characters and personalities. They are religious, tolerant, communicative, peace-loving, and environment-caring.

\subsection{Local Wisdom Values in the Nyadran Tradition}

The nyadran tradition has moral character values horizontally and vertically. Vertical moral values indicate the relationship necessarily maintained spiritually and harmoniously between human and God as a realization of how grateful human is on His mercy. Meanwhile, horizontal moral values refer to positive relationships between human and human, human and animal, and human and natural environment [14]. From the nyadran procession, humans consistently have to become a responsible organizer. It indicates that humans proportionally utilize animal and natural environment and do not commit vandalism so that disasters are able to be avoided. Since these local wisdom values are developed, children personality and character are constructed well. These values are deeply described in the followings.

1. Deliberation value

Deliberation value is actualized as the nyadran tradition ceremony is prepared. There is a great meeting to build nyadran committee. This deliberation is usually called rembug warga. This probably builds students' communicative character.

2. Mutual cooperation and environment-caring values 
These values are realized by the society with activities of cleaning tombs and village environment together. This can build environment-caring character and stimulates harmonious feeling.

3. Communicative Value

Communicative attitude is reflected by moms when they cook foods and sesaji (ritual offerings) used in the nyadran ceremony. They are pleasure to ask one another if need anything for preparing foods and sesaji. Without their communicative attitude, miscommunication will definitely occur. Besides, the communicative attitude is also reflected in the procession of nyadran, in which the society need to walk for reaching the graveyard. This aims to make the society greet one another so that the familial relationship is maintained. This representation of communicative attitude is able to build students' communicative character, realized in daily life in terms of school and society environments.

4. Harmonious Value

Harmonious value is represented by creating peacefulness and serenity among society before nyadran takes place and after nyadran finishes. Hence, the nyadran tradition is able to developed into culture and tradition in the society. This may build peace-loving character among students. This character is reflected by students with different religion, race, ethnicity, custom, and tradition by maintaining harmony one another.

5. Sharing value

Nyadran tradition ceremony is conducted by Muslim society, but still, there are some nonMuslims contributing in cleaning environment and tombs. In the end of the ceremony, participants set the foods aside for non-Muslim. While they have different religion, their tolerance is certainly strong as they keep living harmoniously and do not disturb one another. From this reflection, we see how sharing and tolerant attitudes between humans can create the unity. Moreover, these attitudes are potentially applied among students to develop tolerance and respect.

6. Religious value

In the Javanese context, the religious value of nyadran tradition is related to the effort of maintaining human memory, so humans do not forget their origin [15]. The nyadran tradition has reflected principle values of the local tradition and religious lessons [16]. These principle values are brotherhood, affection, mutual help, amar ma'ruf nahi munkar (asking for doing goodness and avoiding badness), and equality. These principles remind that each human must be back to God. The nyadran tradition has become the religion lesson, in which contents include salvation prayer, salawat recitation, and tahlilan (a salvation ritual for celebrating and praying someone death), and grateful expression to God, the natural creature, due to His mercy. These activities definitely build religious character among students.

7. Generous value

Generous value is performed by sharing foods and crops among society after the nyadran ceremony. This tradition is known as pungguhan. It is a realization of character education to mutually sharing among humans without differentiate one another.

These values are basically indicated from national ideology (Pancasila or five principles). These are able to strengthen the national integration through each stage in the procession before, during, and after the nyadran tradition. Local wisdoms are based on values that are considered good and true and maintained in a long period [17]. Hence, wisdom values of the local society can truly used as an instrument for strengthening the national integration. This condition is because of that local wisdom can be understood an inter-generation knowledge, which is useful 
for the society while being in contact to family, neighbor, other societies, and surrounding environment [18].

In a consequence, basic education absolutely become an effective program of implanting life awareness in varied culture in terms of local wisdoms, which grow and develop in the society. Education practically is a system underlining three educational centers, including family, school, and society. These educational environments have each responsibility and role in implanting awareness on cultural diversity in the multicultural life [19]. Local wisdoms are basically part of Indonesian people's identities, which are dynamic, so the development will bring impacts for local wisdoms in the society. Therefore, participation and role of all society components are necessary to maintain local wisdom values.

\section{CONCLUSIONS}

Nyadran has local wisdom values used for building communicative, environment-caring, peace-loving, tolerant, religious, and sharing characters among elementary students, developed in learning materials. Local wisdom values in the nyadran tradition are (1) deliberation, reflected in the meeting for organizing nyadran committee; (2) mutual cooperation and environment-caring values, represented in activities of cleaning tombs and village environment mutually; (3) creative and communicative values, indicated in the procession of cooking sesaji; (4) harmonious value, actualized by peacefulness and serenity while the nyadran procession is taking place; (5) sharing, tolerant and unity values, showed in the attitude of helping one another, even different religion, during the nyadran procession; (6) religious value, manifested by expressing the society's gratefulness to God in terms of praying and reciting short Surah; and (7) generous value, exemplified by sharing foods among society after the nyadran ceremony. By introducing nyadran tradition, students are not only able to know it but also deeply understand its local wisdom values to, then, be applied in their daily life as a realization of student character building.

\section{REFERENCES}

[1] O. Chen and D. Han, "Rediscovering the Idea of Cultural Heritage and the Relationship with Nature: Four Schools of Essential Thought of the Ancient Han Chinese," Heritage, vol. 2, no. 3, pp. 1812-1834, 2019.

[2] E. El Faisal and S. Sulkipani, "Pengembangan Bahan Ajar berbasis Muatan Lokal pada Mata Kuliah Pendidikan Kewarganegaraan," J. Civ. Media Kaji. Kewarganegaraan, vol. 13, no. 2, pp. 113-126, 2016.

[3] F. FITRIYANTI, E. L. FAISAL, S. SAFITRI, and E. ERIAWATY, "Development of Instructional Materials based Local Wisdom in Social Studies," in Sriwijaya University Learning and Education International Conference, 2016, vol. 2, no. 1, pp. 395-408.

[4] G.-J. Hwang, S.-C. Chang, P.-Y. Chen, and X.-Y. Chen, "Effects of Integrating an Active Learning-Promoting Mechanism into Location-based Real-World Learning Environments on Students' Learning Performances and Behaviors," Educ. Technol. Res. Dev., vol. 66, no. 2, pp. 451-474, 2018.

[5] U. M. I. CHOTIMAH, "Implementation of Character Education Local Wisdom Charged in basic Education Level in South Sumatra," in Sriwijaya University Learning and Education International Conference, 2016, vol. 2, no. 1, pp. 1221-1238.

[6] S. Sudjarwo, S. Sunyono, and H. Herpratiwi, "Multicultural Approach Based Education Model Contribution Towards Apreciation of the Values of Local Wisdom of 
Elementary School Students in Bandar Lampung Indonesia," Turkish Online J. Des. Art Commun., vol. 8, pp. 24-30, 2018.

[7] A. Spyrtou et al., "Transferring a Teaching learning Sequence between Two Different Educational Contexts: The Case of Greece and Finland," Int. J. Sci. Math. Educ., vol. 16, no. 3, pp. 443-463, 2018.

[8] M. Q. Patton, Qualitative Evaluation and Research Methods. New York: SAGE Publications, inc, 1990.

[9] L. J. Moleong, Metodologi Penelitian Kualitatif edisi Revisi. Bandung: PT. Remaja Rosda Karya, 2014.

[10] V. D. W. I. JAYANTI, "Makna Simbol dalam Upacara Pernikahan Adat Sunda Perspektif Teori Bentuk Simbolik Ernst Cassirer." Universitas Gadjah Mada, Yogyakarta, 2013.

[11] H. Sanaky, "Sakral (sacred) dan Profan: Studi Pemikiran Emile Durkheim tentang Sosiologi Agama," IMakalah Disk. Kelas, Progr. Dr. [S-3] Univ. Islam Negeri Sunan Kalijaga, Yogyakarta, vol. 6, 2005.

[12] Y. Hendrawanto, "Pemilihan Novel Indonesia Bermuatan Nilai Kearifan Lokal Sebagai Alternatif Bahan Ajar Teks Cerita Fiksi," Deiksis J. Pendidik. Bhs. dan Sastra Indones., vol. 4, no. 1, pp. 46-53, 2017.

[13] Y. Kartini, "Tembang Dolanan Anak-Anak Berbahasa Jawa Sumber Pembentukan Watak dan Budi Pekerti," Makal. Kongr. Bhs. Jawa, vol. 501, 2011.

[14] A. B. Amin et al., "Association of Moral Values with Vaccine Hesitancy," Nat. Hum. Behav., vol. 1, no. 12, p. 873, 2017.

[15] A. ABBAS, "Kesenian Ojhung dalam TRADISI Sedekah Bumi Di Desa Bunbarat Kecamatan Rubaru Kabupaten Sumenep Tahun 1960-2005,” Avatara, vol. 5, no. 1, 2017.

[16] A. Basir, "Nilai Pendidikan Islam dalam Budaya Tenongan Nyadran Suran Di Dusun Giyanti Wonosobo," AL-QALAM, vol. 9, no. 2, 2016.

[17] A. Saptomo, Hukum dan Kearifan Lokal: Revitalisasi Hukum Adat Nusantara. Jakarta: Grasindo, 2010.

[18] K. Kongprasertamorn, "Local Wisdom Environmental Protection and Community Development: the Clam Farmers in Tambon Bangkhunsai, Phetchaburi Province, Thailand," Manusya J. Humanit., vol. 10, no. 1, pp. 1-10, 2007.

[19] I. T. J. Weismann, I. Tolla, and A. Sinring, "The Development of Multicultural Based Cooperative Learning Model to Enhance the Emotional Quotient of the Student of Jaffray Theology Academy of Makassar," Soc. Sci., vol. 13, no. 1, pp. 1-6, 2018. 